\title{
Dephytinisation of soyabean protein isolate with low native phytic acid content has limited impact on mineral and trace element absorption in healthy infants
}

\author{
Lena Davidsson ${ }^{1 *}$, Ekhard E. Ziegler ${ }^{2}$, Peter Kastenmayer ${ }^{3}$, Peter van Dael ${ }^{3}$ and Denis Barclay ${ }^{3}$ \\ ${ }^{1}$ Laboratory for Human Nutrition, Institute of Food Science and Nutrition, Swiss Federal Institute of Technology \\ (ETH), PO Box 474, CH-8803 Rüschlikon, Switzerland \\ ${ }^{2}$ Department of Pediatrics, University of lowa, lowa City, IA 52242, USA \\ ${ }^{3}$ Nestlé Research Centre Lausanne, PO Box 44, 1000 Lausanne 26, Switzerland
}

(Received 15 May 2003 - Revised 8 September 2003 - Accepted 29 October 2003)

\begin{abstract}
Infant formulas based on soyabean protein isolate are often used as an alternative to cows'-based formulas. However, the presence of phytic acid in soya formulas has raised concern about the absorption of trace elements and minerals from these products. The aim of the present study was to evaluate mineral and trace element absorption from regular and dephytinised soya formula in healthy infants. Soyabean protein isolate with a relatively low native content of phytic acid was used for production of a regular soya formula ( $300 \mathrm{mg}$ phytic acid/kg liquid formula) and an experimental formula was based on dephytinised soya protein isolate $(<6 \mathrm{mg}$ phytic acid/kg liquid formula). Using a crossover study design, apparent mineral and trace element absorptions were measured by a stable isotope technique based on $72 \mathrm{~h}$ faecal excretion of non-absorbed stable isotopes ( $\mathrm{Zn}, \mathrm{Fe}, \mathrm{Cu}$ and $\mathrm{Ca}$ ) and by the chemical balance technique (Mn, $\mathrm{Zn}$, $\mathrm{Cu}$ and $\mathrm{Ca}$ ) in nine infants (69-191 d old). Fe absorption was also measured by erythrocyte incorporation $14 \mathrm{~d}$ after intake. The results from the present study demonstrated that $\mathrm{Zn}$ absorption, measured by a stable isotope technique, was significantly greater after dephytinisation (mean value 16.7 v. $22.6 \% ; P=0.03$ ). No other statistically significant differences between the two formulas were observed. The nutritional benefit of dephytinisation was marginal in the present study. Based on these results, the use of soyabean protein isolate with low native content of phytic acid should be promoted for production of soya formulas and adequate addition of ascorbic acid to enhance Fe absorption should be ensured in the products.
\end{abstract}

Soyabean: Phytic acid: Infant formula: Stable isotopes: Dephytinisation: Infants

Infant formulas based on soyabean protein isolate are frequently used as alternatives to cows' formulas, in particular in the USA where a large proportion of formula-milkfed infants are fed soyabean-based products (for review, see Mendez et al. (2002)). Healthy western infants fed on soya formula grow and develop as well as their peers fed on cows' formula (for reviews, see Fomon (1993a) and Mendez et al. (2002)). However, earlier reports demonstrated that children recovering from severe malnutrition gained weight less well when fed on soya formula as compared with a diet based on cows' (Golden \& Golden, 1981). These results were largely attributed to low $\mathrm{Zn}$ bioavailability from the soya formula due to the presence of phytate (myo-inositol hexaphosphate), a major storage form of $\mathrm{P}$ and a potent inhibitor of trace element absorption. $\mathrm{Zn}$ absorption was later demonstrated to be significantly lower from soya formula, as compared with human and cows' formulas in adults (Sandström et al. 1983). In addition, sodium phytate added to cows' formula was shown to reduce $\mathrm{Zn}$ absorption in adults (Lönnerdal et al. 1984). Significantly lower $\mathrm{Fe}$ absorption from infant formulas based on soya, as compared with cows' formula, was also demonstrated in adult women (Derman et al. 1987).

During the last few years, the possibility of removing or degrading phytic acid from soyabean protein isolate, used as the protein source in infant formula, has been explored. However, the nutritional impact of dephytinised soya formula on mineral and trace element absorption has not been evaluated systematically in infants. Dephytinisation of soyabean protein isolate was demonstrated to be a useful approach to improve Fe bioavailability from soya formula in infants (Davidsson et al. 1994), but neither Zn nor $\mathrm{Ca}$ absorption were improved by partial reduction of phytic acid (Ziegler et al. 1990). However, an enhancing effect of dephytinisation of soyabean protein isolate on Mn absorption has been demonstrated in infants (Ziegler et al. 1990) and adults (Davidsson et al. 1995). 
The aim of the present study was to evaluate the effect of dephytinisation of soyabean protein isolate on the absorption of $\mathrm{Fe}, \mathrm{Zn}, \mathrm{Cu}, \mathrm{Ca}$ and $\mathrm{Mn}$ in healthy infants fed soya formula. Soyabean protein isolate with a relatively low native content of phytic acid, before and after enzymatic degradation of phytic acid, was used for production of infant formulas. Phytic acid contents in the two products were 300 and $<6 \mathrm{mg}$ phytic acid/ $\mathrm{kg}$ liquid formula respectively. Apparent absorption of $\mathrm{Zn}, \mathrm{Cu}$ and $\mathrm{Ca}$ were measured by a stable isotope technique based on $72 \mathrm{~h}$ faecal excretion of non-absorbed stable isotopes after intake of $300 \mathrm{~g}$ labelled formula. Apparent absorption of $\mathrm{Mn}, \mathrm{Zn}, \mathrm{Cu}$ and $\mathrm{Ca}$ was evaluated by the chemical balance technique, based on dietary intake and faecal excretion of minerals and trace elements during $72 \mathrm{~h}$. Fe absorption was measured by a stable isotope technique based on erythrocyte incorporation $14 \mathrm{~d}$ after intake, as well as by faecal monitoring. The study had a crossover design, i.e. each infant acted as his/her own control.

\section{Subjects and methods}

\section{Subjects}

The study protocol was approved by the University of Iowa Institutional Review Board and one or both parents gave written consent. Nine apparently healthy full-term infants participated in the study. Five of the nine subjects were girls and four were boys. The study infants included one set of twins and one set of triplets. On the first day of the first metabolic balance study, they ranged in age from 69 to 191 (median 93) d and had a mean body weight of 5.9 (range 4.4-7.4) $\mathrm{kg}$. The infants had been fed formula since birth as the parents' decision. During the study they were fed the assigned study formulas exclusively, with the exception of one infant who, because of his age, was also fed limited amounts of commercially prepared infant foods. No cereal products were included in his diet.

Sample size calculations were based on our previous data on erythrocyte incorporation of $\mathrm{Fe}$ in infants (Davidsson et al. 1994). It was estimated that eight to ten infants would be a sufficient sample size to detect a nutritionally significant difference in erythrocyte incorporation of $50 \%$ with $90 \%$ power (ten infants) or $80 \%$ power (eight infants) and a type I error rate of $5 \%$.

\section{Study design}

The study had a balanced crossover design in which each subject was studied once while receiving the experimental formula (dephytinised formula) and once while receiving the regular soya formula. The diets were fed in predetermined random order. Each study consisted of a $10 \mathrm{~d}$ washout period followed by a $3 \mathrm{~d}$ period during which a metabolic balance was conducted.

\section{Formulas}

The formulas were produced especially for the present study at the Nestlé Product Technology Centre (Konolfingen, Switzerland). The composition of the products was similar to a commercial infant formula (Alsoy ${ }^{\circledR}$; Carnation ${ }^{\circledR}$, Glendale, CA, USA), except for the use of dephytinised soyabean protein isolate in production of the experimental (dephytinised) formula. Regular and dephytinised formulas were each prepared in two batches. One batch, fed during the washout periods and during the metabolic balance studies, was fortified with $\mathrm{Fe}, \mathrm{Zn}$ and $\mathrm{Cu}$. The other batch, used for the preparation of labelled test meals, was prepared without added Fe, $\mathrm{Zn}$ and $\mathrm{Cu}$. Dephytinised soyabean protein isolate was produced with the use of phytase from Aspergillus niger (Gist-Brocades, Delft, The Netherlands) from commercial soyabean protein isolate (Protein Technologies International, St Louis, MO, USA). The study formulas were prepared in ready-to-feed form.

\section{Experimental procedures}

After the $10 \mathrm{~d}$ washout period, infants were admitted to the Lora N. Thomas Metabolism Ward (Department of Pediatrics, University of Iowa, Iowa City, IA, USA) in the morning. After measurements of weight and length, infants were placed on specially designed metabolic beds. No less than $3 \mathrm{~h}$ after the previous feeding, they were fed $150 \mathrm{~g}$ isotopically labelled formula. This feed also contained $50 \mathrm{mg}$ carmine. The remainder of the labelled formula ( $150 \mathrm{~g})$ was fed as the next feed of the day (about $3 \mathrm{~h}$ later). No additional formula was fed until at least $3 \mathrm{~h}$ after intake of the second labelled test meal. Solid foods (one infant) were withheld for $6 \mathrm{~h}$. The exact amount of formula consumed was determined by weighing feeding bottles before and after feeding. For the remainder of the $72 \mathrm{~h}$ metabolic balance period infants were fed unlabelled study formula. Formula fed exactly $72 \mathrm{~h}$ after intake of the first carmine-containing formula feed also contained carmine. Passage of carmine-stained stool following this second dose marked the end of the metabolic balance period. Infants stayed in the ward during the entire $72 \mathrm{~h}$ collection period. Faeces were collected into acid-washed Pyrex containers using methods described previously (Fomon, 1993b). Faecal samples were weighed, frozen and shipped on dry ice to Switzerland for analysis.

\section{Blood samples and analysis of iron status indices}

Samples of capillary blood (approximately $1 \mathrm{ml}$ ) were obtained before the first isotope administration in each study period and again $14 \mathrm{~d}$ later (total of four blood samples). Blood was obtained by heel prick using a disposable spring-loaded device (Tenderfoot; International Technidyne Corporation, Edison, NJ, USA) and collected in EDTA-treated tubes. Hb was determined using a Coulter Counter (model M430; Coulter Electronics, Hialeah, FL, USA). Plasma was separated from blood cells within 30 min of collection and stored at $-20^{\circ} \mathrm{C}$. Ferritin was analysed by RIA using the Quantimune kit (catalogue no.190-2001; Bio-Rad Laboratories, Hercules, CA, USA).

\section{Preparation of labelled test meals}

Labelled test meals were prepared from infant formula produced without added $\mathrm{Fe}, \mathrm{Zn}$ and $\mathrm{Cu}$. Approximately $12 \mathrm{~h}$ 
before a scheduled isotope administration, $1.2 \mathrm{mg}{ }^{58} \mathrm{Fe}$, $0.25 \mathrm{mg}{ }^{70} \mathrm{Zn}, 0.25 \mathrm{mg}{ }^{65} \mathrm{Cu}$ and $5.0 \mathrm{mg}{ }^{42} \mathrm{Ca}$ were added to $300 \mathrm{~g}$ liquid formula. Test meals were stirred and kept refrigerated until fed.

\section{Stable isotope labels}

$\mathrm{CaCO}_{3}\left(77.746 \%{ }^{42} \mathrm{Ca}\right), \mathrm{ZnO}\left(70.55 \%{ }^{70} \mathrm{Zn}\right)$ and $\mathrm{Cu}$ metal $\left(99.20 \%{ }^{65} \mathrm{Cu}\right)$ were purchased from Medgenix (Ratingen, Germany). Fe metal $\left(91.727 \%{ }^{58} \mathrm{Fe}\right)$ was supplied by Isotec (St-Quentin, France). ${ }^{70} \mathrm{ZnO},{ }^{65} \mathrm{Cu}$ metal and ${ }^{58} \mathrm{Fe}$ metal were dissolved in stoichiometric amounts of $0.5 \mathrm{M}-\mathrm{H}_{2} \mathrm{SO}_{4}$ to prepare metal sulfates. ${ }^{42} \mathrm{CaCO}_{3}$ was dissolved in a stoichiometric amount of $0.5 \mathrm{M}-\mathrm{HCl}$ to obtain $\mathrm{CaCl}_{2}$. Total $\mathrm{Ca}$, $\mathrm{Fe}, \mathrm{Zn}$ and $\mathrm{Cu}$ were measured by flame atomic absorption spectrometry (model 975; Varian, Mulgrave, Victoria, Australia) using external calibration and instrument conditions recommended by the manufacturer. $\mathrm{Ca}$ was analysed after addition of lanthanum oxide (Fluka, Buchs, Switzerland) to a final concentration of $10 \mathrm{~g} \mathrm{La} / 1$. Total concentrations were $2.607 \mathrm{mg} \mathrm{Ca}, 0.850 \mathrm{mg} \mathrm{Fe}, 154.9 \mu \mathrm{g} \mathrm{Cu}$ and $109.7 \mu \mathrm{g} \mathrm{Zn/g}$ solution. The isotopic composition of the labels was measured by thermal ionisation MS (Finnigan MAT Model THQ; Thermoquad, Bremen, Germany). The solutions were placed into acid-washed $5 \mathrm{ml}$ Reacti vials (Pierce, Rockford, IL, USA) and kept refrigerated.

\section{Sample preparation and analysis of faecal samples}

Faecal samples were freeze dried, pooled, homogenised (Compact Robot; Tefal, Selongey, France) and stored in a desiccator until analysis. Pooled samples included the first faecal sample dyed by carmine and all consecutive faecal material up until, but not including, faecal material dyed by the second dose of carmine. Duplicate samples (approximately $300 \mathrm{mg}$ ) were dry ashed for $48 \mathrm{~h}$ in silica Erlenmeyer flasks in a muffle furnace at $520^{\circ} \mathrm{C}$ for measurements of total $\mathrm{Ca}, \mathrm{Cu}, \mathrm{Zn}, \mathrm{Mn}$ and enrichments of ${ }^{42} \mathrm{Ca},{ }^{65} \mathrm{Cu}$ and ${ }^{70} \mathrm{Zn}$. After cooling, $2 \mathrm{ml}$ concentrated $\mathrm{HNO}_{3}$ was added, acid was evaporated to dryness on a hotplate and samples were heated in the muffle furnace overnight at $520^{\circ} \mathrm{C}$. Ash was redissolved in $4 \mathrm{ml}$ concentrated $\mathrm{HCl}$ and diluted to $25 \mathrm{ml}$. Ca and $\mathrm{Cu}$ contents were determined by flame atomic absorption spectrometry. $\mathrm{Zn}$ and Mn were measured by inductively coupled plasma MS using external calibration. A portion of the faecal digest was diluted to $10-100 \mu \mathrm{g} \mathrm{Mn} / 1$ and $100-1000 \mu \mathrm{g} \mathrm{Zn/l}$ in $0 \cdot 5 \mathrm{M}-\mathrm{HNO}_{3}$. Rh $(20 \mu \mathrm{g} / \mathrm{l})$ was used as internal standard. The inductively coupled plasma MS instrument (PerkinElmer Elan 6000; Perkin-Elmer Europe, Rotkreuz, Switzerland) was equipped with a GemTip ${ }^{\text {TM }}$ cross-flow nebuliser and a Scott-type double-pass spray chamber and optimised by using a multielement solution $(10 \mu \mathrm{g} / \mathrm{l}$; Plasma Setup Solution, Perkin-Elmer). The operating conditions were as follows: radio frequency power $1000 \mathrm{~W}$, nebuliser Ar flow rate $0.831 / \mathrm{min}$, mass resolution $0.8 \mathrm{Da}$ at $10 \%$ peak height. The following data collection variables for $\mathrm{Mn}$ and $\mathrm{Zn}$ were used: detector mode, pulse counting; mode, peak hopping; selected isotopes, ${ }^{64} \mathrm{Zn}$ and ${ }^{55} \mathrm{Mn}$; dwell time, ${ }^{64} \mathrm{Zn} 10 \mathrm{~ms},{ }^{55} \mathrm{Mn} 20 \mathrm{~ms}$; sweeps 100 ; number of replicates 5 ; sample uptake rate $1.2 \mathrm{ml} / \mathrm{min}$.
Accuracy of analysis was verified by analysing the National Institute of Standards and Technology's (Gaithersburg, MD, USA) standard reference material bovine liver (1577b) and a pooled human faecal sample. $\mathrm{CV}$ for $\mathrm{Cu}, \mathrm{Zn}$ and $\mathrm{Mn}$ were 3.4, 6.6 and 4.0\% ( $n$ 14; bovine liver) respectively and results were within the range of the certified values. $\mathrm{CV}$ for $\mathrm{Ca}, \mathrm{Cu}, \mathrm{Zn}$ and $\mathrm{Mn}$ were $5.2,3.3$ and 2.6 and $3.5 \%$ respectively ( $n$ 10; inhouse-prepared pool of faecal material). Zn was separated from matrix elements by anion exchange (resin AG1-X8, 200-400 mesh, Cl-form; Bio-Rad Laboratories, Glattbrugg, Switzerland) and $\mathrm{Ca}$ was precipitated with a saturated basic ammonium oxalate solution (Davidsson et al. 1996). $\mathrm{Ca}$ and $\mathrm{Zn}$ isotope ratios were determined by thermal ionisation MS. Instrumental mass discrimination was corrected for by measuring $\mathrm{Ca}$ and $\mathrm{Zn}$ isotope ratios of $\mathrm{CaNO}_{3}$ and $\mathrm{ZnNO}_{3}$ standards with natural isotopic composition (Merck, Darmstadt, Germany). The ratio correction factor was recalibrated for every batch of samples. Within-run precision was $<0.5 \%$ for ${ }^{40} \mathrm{Ca} /{ }^{42} \mathrm{Ca}$ and $<1 \%$ for ${ }^{68} \mathrm{Zn} /{ }^{70} \mathrm{Zn}$. Relative external precision determined by measuring baseline samples was $0.61 \%$ for ${ }^{40} \mathrm{Ca} /{ }^{42} \mathrm{Ca}$ and $0.40 \%$ for ${ }^{68} \mathrm{Zn} /{ }^{70} \mathrm{Zn}(n \mathrm{17})$. After correction for instrumental mass discrimination, isotope ratios for basal faecal samples were within $0.8 \%$ of the accepted International Union of Pure and Applied Chemistry values (Rosman \& Taylor, 1998). Cu isotope ratios were determined by inductively coupled MS. Samples of digested fecal samples were diluted to $0.1 \mathrm{mg} \mathrm{Cu} / \mathrm{l}$ with $0.5 \mathrm{M}-\mathrm{HNO}_{3}$. The following variables for data collection were used: detector mode, pulse counting and peak hopping; dwell time ${ }^{63} \mathrm{Cu}$ and ${ }^{65} \mathrm{Cu} 50 \mathrm{~ms}$; sweeps 100; number of replicates five. Instrumental mass discrimination was corrected for by measurements of $\mathrm{Cu}$ isotope ratios in $0.1 \mathrm{mg} \mathrm{Cu} / 1$ with natural isotopic composition $(\mathrm{Cu}$ standard solution; Merck). The ratio correction factor was recalibrated every ten samples. After correction for instrumental mass discrimination, ${ }^{65} \mathrm{Cu} /{ }^{63} \mathrm{Cu}$ isotope ratios for baseline faecal samples were within $0.30 \%$ of the accepted International Union of Pure and Applied Chemistry value (Rosman \& Taylor, 1998). Accuracy was also verified by spiking baseline faecal samples with known amounts of highly enriched ${ }^{65} \mathrm{Cu}$. Regression analysis of data based on measured isotopic ratios and calculated isotopic ratios resulted in the following equation: $y=-0.00036+$ $1.00153 x\left(R^{2} 0.9997\right)$. The $95 \% \mathrm{CI}$ for the slope and intercept were $(0.999324,1.009821)$ and $(-0.0664,0.00593)$ respectively. Average within-run precision based on five replicates was $0.66 \%$. Repeatability determined by measuring baseline samples was $<0.63 \%$ ( $n$ 34). The detection limit for enrichment of ${ }^{65} \mathrm{Cu}$ in faeces calculated using the average internal relative standard deviation according to Patterson et al. (1999) was 0.89\%.

Total $\mathrm{Fe}$ and ${ }^{58} \mathrm{Fe}$ in faeces were determined by doubleisotope dilution, as this technique was more precise than atomic absorption spectroscopy for analysis of $\mathrm{Fe}$ in faecal material (see later). Faecal samples were spiked with a known amount of enriched ${ }^{57} \mathrm{Fe}$ followed by measurements of the isotopic ratios ${ }^{57} \mathrm{Fe} /{ }^{56} \mathrm{Fe}$ and ${ }^{58} \mathrm{Fe} /{ }^{56} \mathrm{Fe}$. The ${ }^{57} \mathrm{Fe}$-spike was prepared by dissolving $84.2 \mathrm{mg} \mathrm{Fe}$ metal $\left(95.15 \%{ }^{57} \mathrm{Fe}\right)$ in $1 \mathrm{ml}$ concentrated 
$\mathrm{HNO}_{3}+4 \mathrm{ml} \mathrm{H}_{2} \mathrm{O}$. The solution was diluted to approximately $200 \mathrm{mg} \mathrm{Fe} / \mathrm{kg}$. Fe concentration of the solution was $203.26(\mathrm{SD} 0.50) \mathrm{mg} / \mathrm{kg}(n$ 4) as determined by reverse isotope dilution using a $200 \mathrm{mg} \mathrm{Fe} / \mathrm{l}$ standard $\left(\mathrm{Fe}\left(\mathrm{NO}_{3}\right)_{2}\right.$; Merck). Faecal samples (approximately $250 \mathrm{mg}$ ) were mineralised in Teflon perfluoralcoxy copolymer (PFA) digestion bombs (maximum pressure $1400 \mathrm{kPa}$ ) after addition of concentrated $\mathrm{HNO}_{3}$ and $\mathrm{H}_{2} \mathrm{O}_{2} \quad(300 \mathrm{ml} / \mathrm{l})$ using a microwave digestion system with pressure control (MDS-2000; CEM Corp., Matthews, NC, USA). Solutions were diluted to $25 \mathrm{ml}$ and a portion $(7 \mathrm{~g})$ was spiked with $0.3-1.0 \mathrm{~g}{ }^{57} \mathrm{Fe}$ to obtain a ${ }^{57} \mathrm{Fe} /{ }^{56} \mathrm{Fe}$ isotope ratio of approximately $0.5-1.0$ in the sample. Fe concentrations determined by atomic absorption spectroscopy during quantitative analysis of $\mathrm{Ca}$ and $\mathrm{Cu}$ were used for these calculations. $\mathrm{Fe}$ in spiked samples was separated from matrix elements by anion exchange chromatography followed by determination of isotope ratios by thermal ionisation MS as described previously (Kastenmayer et al. 1994; Davidsson et al. 2000). Within-run precision was $<0.5 \%$ for ${ }^{57} \mathrm{Fe} /{ }^{56} \mathrm{Fe}$ and $<1 \%$ for ${ }^{58} \mathrm{Fe} /{ }^{56} \mathrm{Fe}$. Relative external precision was $0.7 \%$ for ${ }^{57} \mathrm{Fe} /{ }^{56} \mathrm{Fe}$ and $<1.3 \%$ for ${ }^{58} \mathrm{Fe} /{ }^{56} \mathrm{Fe}$ (Merck; $n$ 14). A pooled human faecal sample was analysed as an in-house laboratory standard. Total Fe determined by isotope dilution was 1343 (SD 12) $\mathrm{mg} / \mathrm{kg}$ (CV $0.9 \%, n 14)$ and agreed well with the value established by flame absorption spectroscopy 1311 (SD 90) $\mathrm{mg} / \mathrm{kg}$ (CV 6.9\%, n 10). $\mathrm{CV}$ for ${ }^{58} \mathrm{Fe}$ and total $\mathrm{Fe}$ in the faecal pool were 1.8 and $0.9 \%$ respectively. Blanks were measured by processing known amounts of ${ }^{57} \mathrm{Fe}$-spike together with the samples to monitor sample contamination.

\section{Sample preparation and analysis of blood samples}

Samples of whole blood were analysed in duplicate for Fe isotopic composition according to Davidsson et al. (2000). Samples of whole blood (approximately $400 \mathrm{mg}$ ) were mineralised in a microwave digestion system (see earlier). $\mathrm{Fe}$ isotope ratios were determined by thermal ionisation MS after separation by anion exchange chromatography. Relative external precisions for ${ }^{54} \mathrm{Fe} /{ }^{56} \mathrm{Fe},{ }^{57} \mathrm{Fe} /{ }^{56} \mathrm{Fe}$ and ${ }^{58} \mathrm{Fe} /{ }^{56} \mathrm{Fe}$ ratios in baseline blood samples were 0.74 , 0.39 and $0.51 \%$ ( $n$ 8). Relative accuracies of the ${ }^{54} \mathrm{Fe} /{ }^{56} \mathrm{Fe},{ }^{57} \mathrm{Fe} /{ }^{56} \mathrm{Fe}$ and ${ }^{58} \mathrm{Fe} /{ }^{56} \mathrm{Fe}$ ratios of baseline blood samples after correction for fractionation were within $2 \%$ of the accepted absolute Fe isotopic composition determined by the Central Bureau for Nuclear Measurements (Geel, Belgium; Taylor et al. 1992).

All acids were purified by sub-boiling in a quartz still (Kürner Analysentechnik, Rosenheim, Germany). Other chemicals were analytical grade purity. Only ultrapure water $(18 \mathrm{M} \Omega)$ was used. To minimise contamination through vessel material, only acid-washed quartz, polytetrafluoroethylene and polyethylene containers were used.

\section{Calculation of apparent absorption; stable isotopes and chemical balances}

Fractional apparent absorptions of ${ }^{42} \mathrm{Ca},{ }^{65} \mathrm{Cu}$ and ${ }^{70} \mathrm{Zn}$ were calculated based on $72 \mathrm{~h}$ faecal excretion of stable isotopes ingested with the labelled test meals (300 g formula), according to Turnlund et al. (1982). For ${ }^{58} \mathrm{Fe}$ fractional absorption, calculations were based on simplified equations derived from triple-spiking calculations described by Turnlund et al. (1993). The amount of ${ }^{58} \mathrm{Fe}$ incorporated into erythrocytes $14 \mathrm{~d}$ after administration of the labelled test meals was calculated as described in detail previously (Kastenmayer et al. 1994). Apparent absorptions of $\mathrm{Ca}, \mathrm{Cu}, \mathrm{Zn}$ and $\mathrm{Mn}$ were calculated based on the analysis of the total amount of elements in diet and faeces collected during the $72 \mathrm{~h}$ balance period.

\section{Food analyses}

$\mathrm{Ca}$ and $\mathrm{Zn}$ were analysed by flame atomic absorption spectroscopy after dry-ashing (see earlier). $\mathrm{Cu}$ and $\mathrm{Mn}$ contents were determined by graphite furnace atomic absorption spectrometry (SpectrAA 400 Zeeman; Varian) using standard addition to minimise matrix effects and microwave digestion. Pyrolytically coated graphite tubes (Varian) were used. The furnace programme included charring at $700^{\circ} \mathrm{C}(\mathrm{Mn}), 800^{\circ} \mathrm{C}(\mathrm{Cu})$ and atomisation at $2400^{\circ} \mathrm{C}$ $(\mathrm{Mn}), 2300^{\circ} \mathrm{C}(\mathrm{Cu})$. The National Institute of Standards and Technology's standard reference materials wheat flour 1667a and non-fat powder 1549 were analysed for quality control. Phytic acid content (inositol phosphates 5 and 6) was determined by ion pair reverse-phase HPLC after extraction with $2.4 \% \mathrm{HCl}$ (Sandberg \& Ahderinne, 1986; Sandberg et al. 1989).

\section{Statistical analyses}

Statistical differences were evaluated by ANOVA, with soya formula, period and sequence as fixed factors and subjects as the tested factor (Senn, 1993). The effects of study period and sequence were not significant $(P>0.05)$. Results are therefore presented as mean values with $P$ values for differences between formulas and $95 \% \mathrm{CI}$ for the formula effect. For Fe absorption data, the CI are asymmetrical as the analysis was performed on log-transformed data in order to account for non-normality. Results for $\mathrm{Fe}$ erythrocyte incorporation and apparent $\mathrm{Fe}$ absorption based on faecal excretion were compared using paired $t$ test. Data were analysed with NCSS 2000 (Number Cruncher Statistical System, Kaysville, UT, USA).

\section{Results}

All infant formulas contained $125-126 \mathrm{~g}$ solids, $2720 \mathrm{~kJ}$ $(650 \mathrm{kcal}), 32 \mathrm{~g}$ fat, $18 \mathrm{~g}$ protein and $150 \mathrm{mg}$ ascorbic $\mathrm{acid} / \mathrm{kg}$ liquid formula. Concentrations of phytic acid, minerals and trace elements are presented in Table 1. After addition of stable isotope labels, the total content of minerals and trace elements per $300 \mathrm{~g}$ formula was $179.3-180.6 \mathrm{mg} \mathrm{Ca}, 2.3-2.5 \mathrm{mg} \mathrm{Fe}, 2.5 \mathrm{mg} \mathrm{Zn}$ and $0 \cdot 34-0.35 \mathrm{mg} \mathrm{Cu}$. Molar ratios of phytic acid relative to the total mineral and trace element contents in the labelled regular soya formula were: $\mathrm{Ca} 0.03, \mathrm{Fe} 3.05, \mathrm{Zn} \mathrm{3.57,}$ $\mathrm{Cu} 25 \cdot 5$.

Mean $\mathrm{Hb}$ concentration was 118 (SD 13) g/l with three infants having concentrations $<110 \mathrm{~g} / \mathrm{l}$. Geometric mean 
Table 1. Concentrations of phytic acid, calcium, iron, copper, zinc and manganese in ready-to-feed soya formula

\begin{tabular}{lcccccc}
\hline Formula* $^{*}$ & Phytic acid $(\mathrm{mg} / \mathrm{kg})$ & $\mathrm{Ca}(\mathrm{mg} / \mathrm{kg})$ & $\mathrm{Fe}(\mu \mathrm{g} / \mathrm{kg})$ & $\mathrm{Cu}(\mu \mathrm{g} / \mathrm{kg})$ & $\mathrm{Zn}(\mu \mathrm{g} / \mathrm{kg})$ & $\mathrm{Mn}(\mu \mathrm{g} / \mathrm{kg})$ \\
\hline Regular (batch A) & 250 & 600 & 7840 & 839 & 8440 & 305 \\
Regular (batch B)† & 300 & 581 & 2940 & 313 & 886 & 303 \\
Dephytinised (batch C) & $<6$ & 593 & 8620 & 738 & 8480 & 303 \\
Dephytinised (batch D)† & $<6$ & 585 & 2800 & 299 & 872 & 303 \\
\hline
\end{tabular}

* Produced especially for the present study at the Nestlé Product Technology Centre (Konolfingen, Switzerland).

† Stable isotope labels were added before administration.

plasma ferritin was $35 \mu \mathrm{g} / \mathrm{l}(+1 \mathrm{sD} 72 \mu \mathrm{g} / \mathrm{l},-1 \mathrm{sD} 17 \mu \mathrm{g} / \mathrm{l})$; no infant had plasma ferritin concentration $<12 \mu \mathrm{g} / \mathrm{l}$.

Results for mineral and trace element apparent absorptions are given in Tables 2 and 3. Zn absorption, measured by a stable isotope technique, was significantly greater from the dephytinised formula (mean value $22.6 \%$ ) than from the regular soya formula (mean value $16.7 \% ; P=0.03$ ). However, apparent absorptions of $\mathrm{Zn}$ from dephytinised and regular soya formula based on $72 \mathrm{~h}$ chemical balance studies were not significantly different. No statistically significant differences in apparent absorptions of $\mathrm{Cu}$ or $\mathrm{Ca}$ were observed with either technique. Mean apparent absorption of Mn increased from 25.4 to $42.1 \%$ (regular formula $v$. dephytinised formula); however, this difference was not statistically significant $(P=0 \cdot 06)$. Erythrocyte incorporation of $\mathrm{Fe}$ stable isotope did not increase significantly after dephytinisation (Table 4; mean values 6.3 v. $8.3 \%$,
$P=0 \cdot 10$ ), nor did apparent $\mathrm{Fe}$ absorption measured by faecal monitoring. Apparent absorption of Fe, based on faecal excretion of the isotope, was significantly greater $(P=0 \cdot 001)$ than erythrocyte incorporation of $\mathrm{Fe}$ from both formulas (Table 4).

\section{Discussion}

The results from the present study demonstrate for the first time the inhibitory effect of phytic acid on $\mathrm{Zn}$ absorption in infants. These results are thus in agreement with our earlier observation in adults, as we found a significant increase in $\mathrm{Zn}$ absorption from soya formula after $100 \%$ dephytinisation; mean $\mathrm{Zn}$ absorption increased from 12 to $22 \%$ (L Davidsson, A Almgren, B Sandström, MA Juillerat and RF Hurrell, unpublished results). In addition, increased $\mathrm{Zn}$ absorption has been demonstrated in adults

Table 2. Apparent absorptions (\%) of zinc, copper and calcium from regular and dephytinised soya formula in nine healthy infants, based on the stable isotope technique*

(Mean values and $95 \%$ confidence intervals)

\begin{tabular}{ccccc}
\hline & Regular soya formula & Dephytinised soya formula & Statistical significance of effect: $P$ & $95 \% \mathrm{Cl}$ \\
\hline $\mathrm{Zn}$ & 16.7 & 22.6 & 0.03 & $0.9,10.8$ \\
$\mathrm{Cu}$ & 31.2 & 35.0 & 0.34 & $-4.9,12.6$ \\
$\mathrm{Ca}$ & 64.2 & 65.6 & 0.57 & $-4.3,7.2$ \\
\hline
\end{tabular}

${ }^{*}$ For details of formulas, subjects and procedures, see Table 1 and p. 288.

Table 3. Apparent absorptions (\%) of zinc, copper, calcium and manganese from regular and dephytinised soya formula in nine healthy infants, based on the chemical balance technique*

(Mean values and $95 \%$ confidence intervals)

\begin{tabular}{|c|c|c|c|c|}
\hline $\mathrm{Zn}$ & $21 \cdot 1$ & 28.4 & 0.20 & $-4 \cdot 7,19 \cdot 2$ \\
\hline $\mathrm{Cu}$ & 41.7 & 38.7 & 0.49 & $-12 \cdot 8,6 \cdot 7$ \\
\hline $\mathrm{Mn}$ & $25 \cdot 4$ & $42 \cdot 1$ & 0.06 & $-0.8,34.2$ \\
\hline
\end{tabular}

${ }^{*}$ For details of formulas, subjects and procedures, see Table 1 and p. 288.

Table 4. Iron absorption (\%), based on erythrocyte incorporation of stable isotopes $14 \mathrm{~d}$ after intake and on faecal excretion of non-absorbed isotopes during $72 \mathrm{~h}$ balances in nine healthy infants*

(Mean values and $95 \%$ confidence intervals)

\begin{tabular}{|c|c|c|c|c|}
\hline Methodology & Regular soya formula & Dephytinised soya formula & Statistical significance of effect: $P$ & $95 \% \mathrm{Cl}$ \\
\hline Erythrocyte incorporation & $6 \cdot 3$ & $8 \cdot 3$ & $0 \cdot 10$ & $-0.4,5 \cdot 2$ \\
\hline Faecal excretion & $13 \cdot 9$ & $16 \cdot 8$ & 0.40 & $-4 \cdot 2,15 \cdot 5$ \\
\hline
\end{tabular}

${ }^{*}$ For details of formulas, subjects and procedures, see Table 1 and p. 288. 
after degradation of phytic acid in cereals. Nävert et al. (1985) reported significantly higher $\mathrm{Zn}$ absorption from bread containing wheat bran after prolonged leavening and Kivistö et al. (1989) reported significantly higher Zn absorption from extruded crispbread prepared from wheat bran with reduced phytic acid content. Recently, Zn absorption by adults from a complementary food based on wheat and soyabean was demonstrated to be significantly enhanced after dephytinisation (Egli, 2001).

Although the inhibitory effect of phytic acid has not previously been reported in infants, studies in young animals (rat pups and infant rhesus monkeys) demonstrated increased $\mathrm{Zn}$ absorption from low-phytic-acid soya formula (Lönnerdal et al. 1988, 1999). The phytic acid contents were 410 v. $44 \mathrm{mg} / \mathrm{l}$ (Lönnerdal et al. 1988) and $300 \mathrm{mg}$ v. $60 \mathrm{mg} / \mathrm{l}$ (Lönnerdal et al. 1999) before and after dephytinisation respectively. The lack of effect of partial reduction of phytic acid in soya formula on $\mathrm{Zn}$ absorption in infants reported by Ziegler et al. (1990) was probably due to the relatively high content of phytic acid present in both products: 123 and $292 \mathrm{mg}$ phytic acid/l respectively.

Our previous studies in infants demonstrated that dephytinisation of soyabean protein isolate could be a useful approach to improve Fe bioavailability from soya formula as $\mathrm{Fe}$ absorption, measured by a stable isotope technique based on erythrocyte incorporation of $\mathrm{Fe}$, increased significantly after degradation of $100 \%$ or $83 \%$ phytic acid (Davidsson et al. 1994). The lack of effect of dephytinisation on Fe absorption in the present study was therefore somewhat surprising. However, it is important to stress that the native phytic acid content in the soya formulas was about $30 \%$ greater in the study of Davidsson et al. (1994) than in the present study. These results indicate that the effect of dephytinisation is more pronounced when applied to soyabean protein isolate with higher native content of phytic acid. Furthermore, ascorbic acid is a potent enhancer of $\mathrm{Fe}$ absorption that can overcome the inhibiting effect of phytic acid when present in high enough quantities. For example, our previous studies in infants demonstrated that $\mathrm{Fe}$ bioavailability could be enhanced to the same extent by dephytinisation or by increasing the ascorbic acid:Fe molar ratio from $2 \cdot 1$ to 4.2 (Davidsson et al. 1994). In the present study, ascorbic acid was obviously effective in counteracting the inhibitory effect of phytic acid on $\mathrm{Fe}$ absorption in the regular soya formula. These results are thus in agreement with a previous study where no additional effect of dephytinisation of an infant cereal with low native phytic acid content $(0.08 \%)$ and added ascorbic acid (molar ratio 2:1 relative to $\mathrm{Fe}$ ) was observed in infants (Davidsson et al. 1997). In the present study we evaluated Fe absorption by a stable isotope technique based on erythrocyte incorporation of ${ }^{57} \mathrm{Fe}$ and ${ }^{58} \mathrm{Fe}$ as well as by faecal excretion of the isotopes. No statistically significant difference in $\mathrm{Fe}$ absorption was observed between the two soya formulas with either stable isotope technique. However, our observation that fractional $\mathrm{Fe}$ absorption differed based on erythrocyte incorporation as compared with results based on faecal excretion are in agreement with the previous study by Fomon et al. (2000) and highlight some of the methodological limitations of using erythrocyte incorporation as a proxy for $\mathrm{Fe}$ absorption in infants.

Very limited information is available on $\mathrm{Cu}$ absorption in infants and no results on the effect of phytic acid on $\mathrm{Cu}$ absorption during early life have been reported previously. Our present results are in agreement with earlier studies in adult human subjects (Turnlund et al. 1985; Egli, 2001) and in rat pups and infant rhesus monkeys (Lönnerdal et al. 1999), demonstrating no inhibiting effect of phytic acid on $\mathrm{Cu}$ absorption. Furthermore, only limited information is available on $\mathrm{Ca}$ absorption from soyabean products in human subjects and, to our knowledge, the effect of complete dephytinisation of soya formulas on $\mathrm{Ca}$ absorption has not been evaluated previously in infants. However, Heaney et al. (1991) reported significantly greater Ca absorption from soyabeans with low phytic acid content as compared with soyabeans with higher phytic acid content in adult women. Ca absorption measured by a stable isotope technique was relatively high in the present study: mean values were about $65 \%$ for both soya formulas, and were similar to recent results on $\mathrm{Ca}$ absorption from a cows'-based infant formula containing lactose (Abrams et al. 2002). The study by Abrams et al. (2002) reported $\mathrm{Ca}$ absorption, measured by a stable isotope technique, to be 66 (SD 12) \% in eighteen infants. The results from the present study thus indicate that modern soya infant formulas provide similar amounts of absorbed $\mathrm{Ca}$ as cows'based formula and that $\mathrm{Ca}$ absorption is not inhibited from soya formula based on soyabean protein isolate with low native content of phytic acid.

In conclusion, the aim of the present study was to investigate the effect of dephytinisation of soyabean protein isolate on mineral and trace element absorption in healthy infants fed soya formula as part of the ongoing efforts to improve the nutritional quality of comercially produced infant foods. However, the nutritional benefit of dephytinisation was marginal in the present study. The results clearly indicate that the use of soyabean protein isolate with low native phytic acid content should be promoted for production of infant formulas and adequate addition of ascorbic acid to enhance Fe absorption should be ensured in the products. However, dephytinisation as a strategy to improve mineral and trace element absorption from foods with high phytic acid content, for example complementary foods based on cereals and legumes consumed by infants and young children in developing countries, should be evaluated for long-term effects on childhood nutrition and health.

\section{Acknowledgements}

The authors are grateful for the cooperation of all infants and their parents during the study. Mrs Joan Frantz and her colleagues in the Lora N. Thomas Metabolism Ward provided excellent care and technical assistance during the study. We also thank Mrs Jennifer Clough, Mrs Karin Longet and Mr Mario Vigo for expert technical assistance and Mr Andreas Rytz for statistical analyses of the results. Financial support by Nestec Ltd, Vevey, Switzerland, is gratefully acknowledged. 


\section{References}

Abrams SA, Griffin IJ \& Davila PM (2002) Calcium and zinc absorption from lactose-containing and lactose-free infant formulas. Am J Clin Nutr 76, 442-446.

Davidsson L, Almgren A, Juillerat M-A \& Hurrell RF (1995) Manganese absorption in humans: The effect of phytic acid and ascorbic acid in soy formula. Am J Clin Nutr 62, 984-987.

Davidsson L, Galan P, Cherouvrier F, et al. (1997) Iron bioavailability from infant cereals by infants: The effect of dephytinization. Am J Clin Nutr 65, 916-920.

Davidsson L, Galan P, Kastenmayer P, et al. (1994) Iron absorption in infants: The influence of phytic acid and ascorbic acid in formulas based on soy isolate. Pediatr Res 36, 816-822.

Davidsson L, Kastenmayer P, Szajewska H, Hurrell RF \& Barclay D (2000) Iron bioavailability in infants from an infant cereal fortified with ferric pyrophosphate or ferrous fumarate. Am J Clin Nutr 71, 1597-1602.

Davidsson L, Mackenzie J, Kastenmayer P, Aggett PJ \& Hurrell RF (1996) Zinc and calcium apparent absorption from an infant cereal. A stable isotope study in healthy infants. $\mathrm{Br} J$ Nutr $\mathbf{7 5}$, $291-300$.

Derman DP, Ballot D, Bothwell TH, et al. (1987) Factors influencing the absorption of iron from soya-bean protein products. $\mathrm{Br}$ J Nutr 57, 345-353.

Egli I (2001) Traditional food processing methods to increase mineral bioavailability from cereal and legume based weaning foods, $\mathrm{PhD}$ thesis no. 13980, Swiss Federal Institute of Technology.

Fomon SJ (1993a) Infant formulas. In Nutrition of Normal Infants, pp. 424-433 [SJ Fomon, editor]. St Louis, MO: Mosby.

Fomon SJ (1993b) Procedures for collection of urine and feces and for metabolic studies. In Nutrition of Normal Infants, pp. 459-464 [SJ Fomon, editor]. St Louis, MO: Mosby.

Fomon SJ, Ziegler EE, Serfass RE, et al. (2000) Less than $80 \%$ of absorbed iron is promptly incorporated into erythrocytes of infants. $J$ Nutr 130, 45-52.

Golden BE \& Golden MHN (1981) Plasma zinc, rate of weight gain, and the energy cost of tissue deposition in children recovering from severe malnutrition on a cow's or soya protein based diet. Am J Clin Nutr 34, 892-899.

Heaney RP, Weaver CM \& Fitzsimmons ML (1991) Soybean phytate content: effect on calcium absorption. Am J Clin Nutr 53, 745-747.

Kastenmayer P, Davidsson L, Galan P, et al. (1994) A double stable isotope technique for measuring iron absorption in infants. Br J Nutr 71, 411-424.

Kivistö B, Cederblad A, Davidsson L, Sandberg A-S \& Sandström B (1989) Effect of meal composition and phytate content on zinc absorption in humans from an extruded bran product. J Cereal Sci 10, 189-197.

Lönnerdal B, Bell JG, Hendrickx AG, Burns RA \& Keen CL
(1988) Effect of phytate removal on zinc absorption from soy formula. Am J Clin Nutr 48, 1301-1306.

Lönnerdal B, Cederblad A, Davidsson L \& Sandström B (1984) The effect of individual components of soy formula and cow's formula on zinc bioavailability. Am J Clin Nutr 40, $1064-1070$.

Lönnerdal B, Jayawickrama L \& Lien EL (1999) Effect of reducing the phytate content and of partially hydrolyzing the protein in soy formula on zinc and copper absorption and status in infant rhesus monkeys and rat pups. Am J Clin Nutr 69, 490-496.

Mendez MA, Anthony MS \& Arab L (2002) Soy-based formulae and infant growth and development: A review. J Nutr 132, $2127-2130$

Nävert B, Sandström B \& Cederblad A (1985) Reduction of the phytate content of bran by leavening in bread and its effect on zinc absorption in man. Br J Nutr 53, 47-53.

Patterson KY, Veillon C, Hill AD, Moser-Veillon PB \& O'Haver TC (1999) Measurement of calcium stable isotope tracers cool plasma ICP-MS. J Anal At Spectrom 14, $1673-1677$.

Rosman KJR \& Taylor PDP (1998) Isotopic composition of elements. Pure Appl Chem 70, 217-235.

Sandberg A-S \& Ahderinne R (1986) HPLC method for determination of inositol tri-, tetra-, penta-, and hexaphosphates in foods and intestinal contents. J Food Sci 51, 547-550.

Sandberg A-S, Carlsson N-G \& Svanberg U (1989) Effects of tri-, tetra-, penta-, and hexaphosphates on in vitro estimation of iron availability. J Food Sci 54, 159-161.

Sandström B, Cederblad A \& Lönnerdal B (1983) Zinc absorption from human, cow's and infant formulas. Am J Dis Child 137, $726-729$.

Senn S (1993) Cross-over Trials in Clinical Research. New York: Wiley.

Taylor PDP, Maeck R \& De Bièvre P (1992) Determination of the absolute isotopic composition and atomic weight of a reference sample of natural iron. Int J Mass Spectrom Ion Process 121, $111-125$.

Turnlund JR, Keyes WR \& Peiffer GL (1993) Isotope ratios of molybdenum determined by thermal ionisation mass spectrometry for stable isotope studies of molybdenum metabolism in humans. Anal Chem 65, 1717-1722.

Turnlund JR, King JC, Gong B, Keyes WR \& Michael MC (1985) A stable isotope study of copper absorption in young men: effects of phytate and alpha-cellulose. Am J Clin Nutr 42, $18-23$.

Turnlund JR, Michel MC, Keyes WR, King JC \& Margen S (1982) Use of enriched isotopes to determine zinc and iron absorption in elderly men. Am J Clin Nutr 35, 1033-1040.

Ziegler EE, Janghorbani M, Nelson SE \& Edwards BB (1990) Effect of phytate reduction on mineral absorption from soy based infant formula. Am J Clin Nutr 51, 528, Abstr. 